\title{
Assessing the soil color by traditional method and a smartphone: a comparison
}

\author{
Evaluación del color del suelo por el método tradicional y \\ un smartphone: una comparación
}

\begin{abstract}
Gabriela Talita de Castro Raulino ${ }^{1}$; Lucas de Sousa Oliveira ${ }^{2}$; Ícaro Vasconcelos do Nascimento ${ }^{3}$; Cillas Pollicarto da Silva ${ }^{4}$; Márcio Godofrêdo Rocha Lobato ${ }^{5}$; Thiago Leite Alencar ${ }^{6}$; Raul Shiso Toma Francisca Gleiciane da Silva ${ }^{8}$; Jaedson Cláudio Anunciato Mota ${ }^{9}$
\end{abstract} \begin{abstract}
ARTICLE DATA
1 Undergraduate studen, Graduation student, Universidade Federal do Ceará, Ceará, Brasil, gabrielacasttrogc@gmail.com

2 Researcher Ph.D. Student, Universidade Federal do Ceará, Ceará, Brasil, lucasdesousa@alu.ufc.br

3 Ph.D., Student, Universidade Federal do Ceará, Ceará, Brasil, icaro_agro@hotmail.com

4 Professor Dr. Instituto Federal de Educação, Ciência e Tecnologia do Amazonas - Campus, Tefé, Amazonas, Brasil, cillas.silva@ifam.edu.br

5 Professor Dr. Universidade Federal do Cariri Campus Crato. Ceará, Brasil, marciogrl@hotmail.com

6 Professor Dr. Instituto Federal de Educação, Ciência e Tecnologia do Piauí, Pio IX, Piauí, Brasil, thiagoleitealencar@yahoo.com.br

7 Professor Dr. Universidade Federal do Ceará, Ceará, Brasil, raulstoma@ufc.br

${ }^{8}$ Researcher Ph.D. Universidade Federal do Ceará, Ceará, Brasil, gleiciane.silva27@gmail.com

9 Professor Dr. Universidade Federal do Ceará, Ceará, Brasil, jaedson.mota@ufc.br
\end{abstract}

Cite: Raulino, G. T.; Oliveira, L.; Nascimento, I.V.; da Silva, C.; Lobato, M; Alencar, T.L.; Toma, R.S.; da Silva, F.G.; Mota, J.C.A. (2021). Assessing the soil color by traditional method and a smartphone: a comparison. Revista de Ciencias Agrícolas. 38(1): 75-85. doi: https://doi.org/10.22267/rcia.213801.146

Received: October 072020.

Accepted: April 142021.

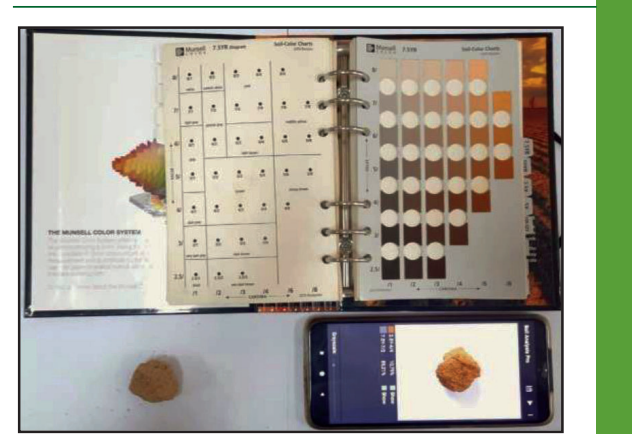

\section{ABSTRACT}

Based on the hypothesis that there is a high agreement between pedologists and a smartphone application in the assessment of soil color, this study aimed to compare the perceptions of pedologists and an application in obtaining the color of an Argissolo [Lixisol] (A, E, and B horizons). Ten aggregates of each horizon were collected. In a single day, under the same lighting conditions, three pedologists described the color components (hue, value, and chroma) of each aggregate (dry and moist soil) using the Munsell soil color chart. Each one of the ten aggregates, from each horizon, was photographed (dry and moist soil sequence) using the camera of a Motorola Moto G4 Plus smartphone. The distance of the camera to the aggregates was $25 \pm 5 \mathrm{~cm}$. Also, each aggregate was placed on a white sheet of A4 size paper (background). The application used was Soil Analysis Pro. The percentage of agreement between pedologists and application was obtained concerning hue, value, and chroma. The data were subjected to analysis of variance, in a completely randomized design, with ten replicates. Action Stat ${ }^{\circledR}$ software was used for statistical analysis. It was concluded that the agreement between pedologists and the smartphone application was medium for hue and chroma and low for value. For the dry soil condition, there is a high agreement between pedologists and the smartphone application, especially in the perception of hue and chroma. Thus, the smartphone application has the potential to be used in routine descriptions of soil color.

Keywords: Pedometrics; Soil analysis pro; Munsell soil color chart; Proximal sensing; Android; Digital camera.

\section{RESUMEN}

Suponiendo que existe un alto acuerdo entre los pedólogos y una aplicación de smartphone en la descripción del color del suelo, el objetivo fue comparar las percepciones de los pedólogos y una aplicación en la obtención del color de un Argissolo [Lixisol] (horizontes A, E y B). Fueron recolectados diez agregados de cada horizonte. En un solo día, en las 
mismas condiciones de iluminación, tres podólogos describieron los componentes del color (matiz, valor y croma) de cada agregado (suelo seco y húmedo) utilizando la tabla de color Munsell. Cada uno de los diez agregados, de cada horizonte, fue fotografiado (secuencia de suelo seco y húmedo) con la cámara de un smartphone Motorola Moto G4 Plus. La distancia de la cámara a los agregados fue de $25 \pm 5 \mathrm{~cm}$. Además, cada agregado se colocó en una hoja blanca de papel A4 (fondo). La aplicación utilizada fue Soil Analysis Pro. El porcentaje de concordancia entre los pedólogos y la aplicación se obtuvo en relación con el matiz, valor y croma. Los datos se sometieron a análisis de varianza en un diseño completamente al azar, con diez repeticiones, utilizando el software Action Stat@. Se llegó a la conclusión de que el acuerdo entre los pedólogos y la aplicación del smartphone era medio en valor y croma y bajo en valor. En suelo seco, existe un alto nivel de acuerdo entre los pedólogos y la aplicación, principalmente en la percepción de matiz y croma. Por lo tanto, la aplicación para smartphone tiene el potencial de usarse en descripciones rutinarias del color del suelo.

Palabras clave: Pedometría; Soil analysis pro; Tabla de color Munsell; Sensado proximal, Android; Cámara digital.

\section{INTRODUCTION}

In the context of soil science, color is one of the most observed intrinsic characteristics. Color evaluation is considered fundamental in the morphological description of the soil and as a primary indicator of its chemical, physical, and mineralogical components (Han et al., 2016; Stiglitz et al., 2017; Stiglitz et al., 2020). Additionally, it is a diagnostic attribute required for soil classification in some taxonomic systems (Santos et al., 2018).

For soil color determination, the prevalent practice is performed through standard visual perception. In this method, experienced pedologists determine the color of a soil sample based on the closest correspondence with one of the standard colors contained in the Munsell color chart (Han et al., 2016; Simon et al., 2020). With this correspondence, soil color is classified in terms of three components, namely: hue (dominant color spectrum), value (lightness), and chroma (color purity or intensity).

Color evaluation in routine descriptions should preferably be done in the moist condition and, when possible, in the dry condition too (Jahn et al., 2006). The determination in moist and dry soil is useful for classification purposes, since some systems, such as the World reference base for soil resources (FAO, 2014), need this information to identify some diagnostic horizons. One example is the Chernic horizon - a surface mineral diagnostic horizon (value of $\leq 3$ moist, and $\leq 5$ dry; and chroma of $\leq 2$ moist - slightly crushed samples) (FAO, 2014).

Soil color determination through standard visual perception, despite being widely used, is considered purely comparative, and therefore, variable due to the technical ability and psychophysical factors of the evaluator (Stiglitz et al., 2016; Kirillova et al., 2018; Pegalajar et al., 2019). Also, it has been shown that factors such as the lighting conditions and the time of use of the chart contribute to reducing the quality of the visual perception of color (Stiglitz et al., 2016). Because of these particularities, the visual evaluation of color by pedologists is considered subjective and subject to a high degree of uncertainty (Marqués-Mateu et al. 2018).

Motivated to find ways to overcome these problems, many soil scientists have resorted to 
alternative methods of color analysis (Stiglitz et al., 2017). In these methods, instruments such as colorimeters, spectroradiometers, and photographic cameras are used to determine the color of soil samples by measuring the spectral reflectance in a range of the electromagnetic spectrum (Pongnumkul et al., 2015; Fan et al., 2017).

Also on this topic, more recently, several studies have focused on the possibility of using smartphone cameras associated with applications to obtain soil color to reduce errors arising from the subjectivity of the observer and facilitate the evaluation. The results have been promising (Han et al., 2016).

When searching for the keywords "soil color" and "smartphone" in the SCOPUS database, 32 articles related to the theme were found, from 2013 to 2021. Thus, interest in the subject began less than ten years ago.

Among the advantages of using a smartphone application to assess soil color, we can mention its agility, reliability, and low operating cost. In addition, the application allows many users to collect and store soil color information quickly and securely. (Stiglitz et al., 2017). As limitations, digital cameras fall short of the human eye in parameters such as visual field and spatial resolution (Skorka and Dileepan, 2011).

In this context, the present study considered the hypothesis that there is a high agreement between pedologists and a smartphone application in the assessment of soil color. Thus, this study aimed to compare the perceptions of pedologists and an application in obtaining the color of an Argissolo [Lixisol] (A.E and Bt1 horizons).

\section{MATERIAL AND METHODS}

We studied a soil profile classified, in the Brazilian Soil Classification System (Santos et al., 2018), as Argissolo Amarelo Eutrocoeso típico [Lixisol] (FA0, 2014) (Figure 1). The profile is located at the Federal University of Ceará, on the Pici Campus, in the Forage Sector of the Animal Science Department, in Fortaleza-CE, Brazil, at the geographic coordinates: $9.856 .297 \mathrm{~m} \mathrm{~N}, 547.050 \mathrm{~m} \mathrm{E}$ (UTM Zone 24S). The soil was described and classified by Vieira (2013).

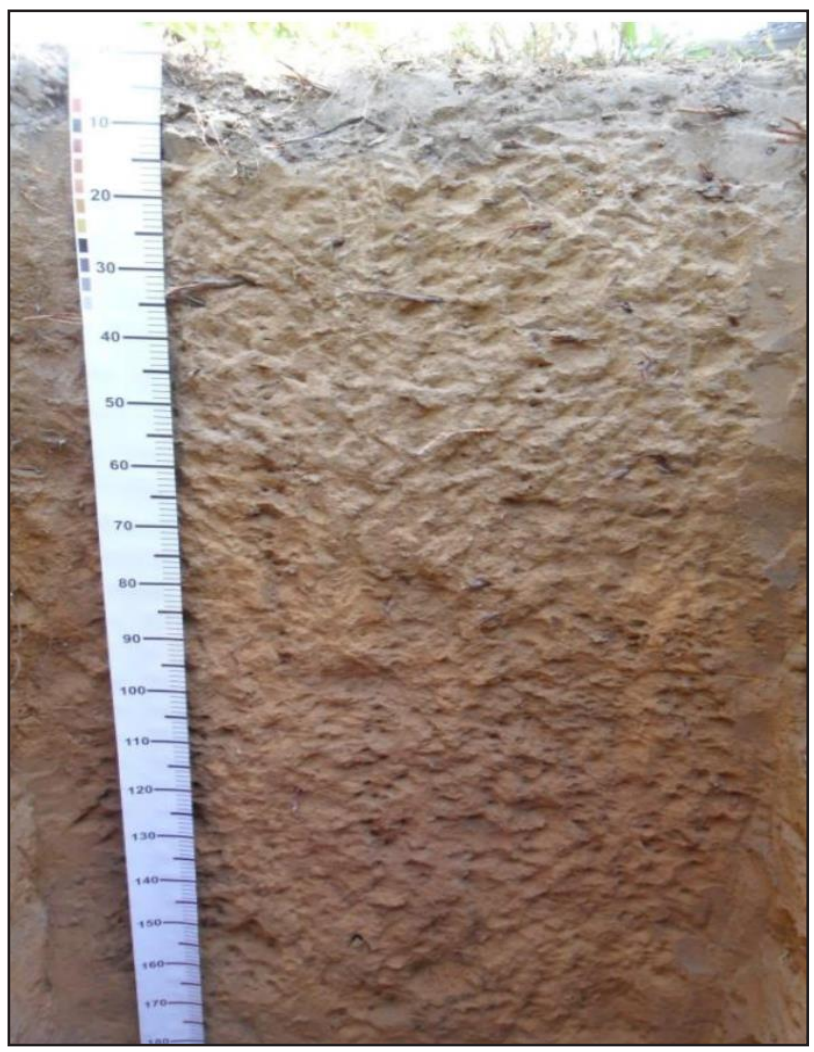

Source: Vieira (2013).

Figure 1. Soil profile - Argissolo Amarelo Eutrocoeso típico [Lixisol].

Horizons Ap1 $(0-10 \mathrm{~cm}), \quad$ E $(17-39 \mathrm{~cm})$, and Bt1 $(63-79 \mathrm{~cm})$ were identified in the morphological description, according to the recommendation and their characterization is presented in Table 1 . 
Table 1. Morphological description of the evaluated horizons.

0-10 cm; very dark grayish brown (10YR 3/2 moist), dark grayish brown (10YR 5/2,

Ap1 dry); granular medium weak and subangular blocky small weak; soft, very friable, nonplastic and non-sticky; flat and clear transition.

$\mathbf{E}$

17-39 cm; dark yellowish-brown (10YR 4/3, moist), yellowish-brown (10YR 5/4, dry); massive; very hard, friable, slightly plastic and slightly sticky; flat and gradual transition.

63-79 cm, brown (7.5YR 5/4 moist), reddish-yellow (7.5YR 6/6, dry); subangular blocky

Bt1 medium to large moderate; hard, very friable, plastic and slightly sticky; clear and flat transition.

A, E, and B horizons were chosen because they are very distinct in terms of color.

The Ap1 horizon, for receiving a supply of organic material, usually has a more darkened color; the E horizon, for being typically a section of eluviation of pigmenting material (oxides, organic material), usually has light colors; while the Bt1 horizon, for being a horizon of accumulation of fine material (clays and oxides), and given the conditions of good soil drainage, has more intense and distinct colors compared to the two overlying horizons. Also, these horizons have heterogeneity regarding the particlesize constitution (Table 2).

Table 2. Particle size and textural class of the evaluated horizons.

\begin{tabular}{|c|c|c|c|c|}
\hline \multirow{2}{*}{ Horizon } & Sand & Silt & Clay & \multirow{2}{*}{ Textural class } \\
\hline & \multicolumn{3}{|c|}{$\left(\mathrm{g} \mathrm{kg}^{-1}\right)$} & \\
\hline Ap1 & 861 & 94 & 45 & Loamy Sand \\
\hline $\mathbf{E}$ & 648 & 164 & 188 & Sandy Loam \\
\hline Bt1 & 580 & 103 & 317 & Sandy Clay Loam \\
\hline
\end{tabular}

Ten aggregates (ten repetitions) of each horizon were collected. In a single day, under the samelighting conditions, three pedologists described the color components (hue, value, and chroma) of each aggregate of the horizons in the dry soil and moist soil, using the Munsell soil color chart (Munsell Color Company, 2009). All the color evaluations followed the recommendations contained in guidelines for soil description published by the Food and Agriculture Organization - FAO (Jahn et al., 2006).

Each one of the ten aggregates, collected in the horizons already mentioned, was photographed in the dry and moist soil sequence using the digital camera of a Motorola Moto G4 Plus smartphone, with the following specifications: 1920 x 1080-pixel resolution screen with a 15.9-megapixel camera with built-in autofocus sensor and Android operating system version 7.0. The device was configured with the ISO parameter (image sensor sensitivity to light) at 100, according to the lighting conditions of the day $(6500 \mathrm{~K})$, white balance in the daylight option for high brightness (1580 lx), and the flash in the off position. The distance of the camera to the aggregates was $25 \pm 5 \mathrm{~cm}$. For color evaluation with the smartphone, each aggregate was placed on a white sheet of A4 size paper ( $210 \times 297 \mathrm{~mm})$ to standardize the background of each photo.

The application used on the smartphone to obtain color information was Soil Analysis 
Pro (Broken Oak Studios, 2017), a freeuse software composed of the following function components: image acquisition, image processing, and color analysis. By clicking "Take new photo", the smartphone automatically enters the image capture and then does the processing and generates the result of the color analysis. The application was configured to display the two predominant colors, with the hue represented by the one with the highest percentage of occurrence. For value and chroma, when they differed for both colors, the representation was made using the arithmetic mean.

Each color component (hue, value, and chroma) was individually evaluated to make the statistical analysis viable and to allow the calculation of the agreement between pedologists and the application. In each horizon, the percentage of agreement between each pedologist and the smartphone camera regarding hue, value, and chroma was obtained considering equation 1 :

$$
\text { Agreement }(\%)=\frac{n-d}{n}
$$

where $n$ is the number of data pairs for each color component (hue, value, and chroma) obtained by the pedologist and the smartphone application; and $d$ is the number of pairs of disagreement between the pedologist and the smartphone application.

Additionally, the data were subjected to analysis of variance, in a completely randomized design with 10 replicates. Action Stat $^{\circledR}$ software (Version 3.17), in a Microsoft Excel $^{\circledR}$ (Version 2016) environment, was used for data processing.

\section{RESULTS AND DISCUSSION}

According to the mean values of modal hues presented in Table 3, there was a 100\% agreement between pedologists and the smartphone application for dry soil and $33 \%$ agreement for moist soil. These results indicate a distinct perception of the dominant spectrum as a function of soil moisture, corroborating the results observed by Han et al. (2016).

Considering the pedologists individually, there was a maximum agreement between the perception of pedologists $\mathrm{A}$ and $\mathrm{C}$ and the smartphone application for dry soil (100\%), while for B the percentage of agreement was only $33 \%$. For the moist soil, the percentage of agreement was 33\% for pedologists A and $\mathrm{B}$, and there was no agreement for pedologist C (Table 3).

The visual evaluation of color from the comparisons with the patterns gathered in the Munsell color chart, despite being easy and fast, has the inconvenience of the subjectivity resulting from the psychophysical characteristics of each human being (Pegalajar et al., 2019; Stiglitz et al., 2016,). Thus, the values of the modal means contained in Table 3 are indicative of a particular interpretation of color, leading to variation in the sensitivity and quality of the spectral response by pedologists (Stiglitz et al., 2017; Stiglitz et al., 2020).

Although the quality of the incident light and the time of use of the color chart also interfere (Fan et al., 2017), these factors are not related to variations observed in the perception by pedologists, because during the obtaining of the color they did not change. 
Table 3. Modal hues observed by pedologists and smartphone application in the color description for horizons of an Argissolo (Lixisol).

\begin{tabular}{|c|c|c|c|c|c|}
\hline \multirow{2}{*}{$\begin{array}{l}\text { Horizon/ } \\
\text { Moisture }\end{array}$} & \multicolumn{4}{|c|}{ Pedologists } & \multirow{2}{*}{ Smartphone } \\
\hline & A & B & C & Modal mean & \\
\hline Ap / Dry & $2.5 Y(8)$ & 7.5YR (8) & $2.5 Y(7)$ & $2.5 Y(8)$ & $2.5 Y(6)$ \\
\hline Ap / Moist & $2.5 Y(8)$ & $2.5 Y(5)$ & $2.5 Y(8)$ & $2.5 Y(7)$ & $5 Y(9)$ \\
\hline E / Dry & $2.5 Y(9)$ & 10YR (6) & $2.5 Y(8)$ & $2.5 Y(8)$ & $2.5 Y(4)$ \\
\hline E / Moist & 10YR (10) & $2.5 Y(9)$ & 10YR (8) & 10YR (9) & $7.5 Y(9)$ \\
\hline Bt / Dry & 10YR (10) & 10YR (10) & 10YR (10) & 10YR (10) & 10YR (10) \\
\hline Bt / Moist & 10YR (10) & 10YR (7) & 7.5YR (10) & 10YR (9) & 10YR (7) \\
\hline
\end{tabular}

The value between parentheses represents the mode in ten observations.

Another factor that results in subjectivity is the selection of the hue page in the Munsell color chart (from $5 \mathrm{R}$ to $5 \mathrm{Y}$ ). The subjectivity is so great that, not infrequently, some pedologists choose to interpolate the hue, which was not the case in this study. MarquésMateu et al. (2018), in a study in which one of the objectives was to evaluate the fragility of obtaining soil color by comparison with Munsell's standards, also highlight the influence of subjectivity in the evaluation of hue by pedologists.

For hue, the agreement between pedologists and the smartphone application (Table 4), for dry soil, was on average 70,63 , and $73 \%$ for pedologists $\mathrm{A}, \mathrm{B}$, and $\mathrm{C}$, with an average of $69 \%$ considering the three pedologists. For the moist soil, the values found were 30,33 , and $10 \%$, respectively, for pedologists $A, B$, and $\mathrm{C}$, with an average value of $25 \%$.

As observed for hue, the tone and intensity of soil color, represented by the value and chroma components, also had variable perception as a function of soil moisture, with higher percentages of agreement in the evaluations performed in dry soil than in moist soil. For the value in dry soil condition, the agreement was 47,27 , and $17 \%$ for pedologists $A, B$, and $C$, respectively, with an average of $30 \%$, while for moist soil the agreement was 13,13 , and $7 \%$, respectively, with an average of $11 \%$ (Table 4).

The marked reduction in the percentage of agreement for value in the moist soil condition may be associated with the particle-size difference between horizons (Table 2). Horizons A and E are composed of coarser fractions, which may have increased the intensity of reflectance and, consequently, caused variation in the perception of the color expression and tone (Simon et al., 2020).

Also in Table 4, for chroma in the dry soil condition, considering the same sequence for the pedologists, the percentages of agreement were $93 \%, 40 \%$, and $60 \%$, respectively, with an average of $64 \%$, while for the moist soil the percentages were $57 \%, 20 \%$, and $47 \%$, respectively, with an average of $41 \%$ for the evaluators. 
Table 4. Agreement between pedologists and the smartphone application in the perception of color (hue, value, and chroma) in horizons of an Argissolo (Lixisol).

\begin{tabular}{cccccc}
\hline \multirow{2}{*}{ Horizon / Moisture } & \multicolumn{5}{c}{ Agreement between pedologists and smart- } \\
& Variable & \multicolumn{4}{c}{ phone (\%) } \\
\cline { 3 - 6 } & & A & B & C & Mean \\
\hline \multirow{3}{*}{ Ap / Dry } & Hue & 60 & 40 & 60 & 53 \\
& Value & 0 & 0 & 0 & 0 \\
& Chroma & 100 & 60 & 90 & 83 \\
& Hue & 20 & 0 & 0 & 7 \\
Ap / Moist & Value & 0 & 0 & 0 & 0 \\
& Chroma & 90 & 30 & 80 & 67 \\
\hline \multirow{3}{*}{ E/ Dry } & Hue & 50 & 50 & 60 & 53 \\
& Value & 90 & 30 & 0 & 40 \\
& Chroma & 100 & 60 & 20 & 60 \\
& Hue & 0 & 0 & 0 & 0 \\
E / Moist & Value & 0 & 0 & 0 & 0 \\
& Chroma & 0 & 0 & 0 & 0 \\
\hline \multirow{3}{*}{ Bt / Dry } & Hue & 100 & 100 & 100 & 100 \\
& Value & 50 & 50 & 50 & 50 \\
& Chroma & 80 & 0 & 70 & 50 \\
& Hue & 70 & 100 & 30 & 67 \\
Bt / Moist & Value & 40 & 40 & 20 & 33 \\
& Chroma & 80 & 30 & 60 & 57 \\
\hline \multirow{2}{*}{. } & & & & &
\end{tabular}

According to the $\mathrm{F}$ test of the analysis of variance for the data referring to value and chroma in the different soil horizons, in dry and moist conditions (Table 5), except for the value in the Bt horizon when dry and for chroma in the A horizon in both situations of moisture, there was a significant effect of the evaluation method.

Table 5. Analysis of variance for data of value and chroma in horizons of an Argissolo (Lixisol).

\begin{tabular}{ccccccc}
\hline & \multicolumn{7}{c}{ Value } & & & & \\
\hline Horizon/Moisture & Source of variation & DF & SS & MS & F & p-value \\
\hline \multirow{2}{*}{ Ap / Dry } & Evaluation method & 3 & 24.08 & 8.03 & 19.39 & $1.19 \mathrm{E}-07$ \\
& Residual & 36 & 14.90 & 0.41 & & \\
\multirow{2}{*}{ Ap / Moist } & Evaluation method & 3 & 58.90 & 19.63 & 69.29 & $5.02 \mathrm{E}-15$ \\
& Residual & 36 & 10.20 & 0.28 & & \\
\hline \multirow{2}{*}{ E / Dry } & Evaluation method & 3 & 10.50 & 3.50 & 17.03 & $4.74 \mathrm{E}-07$ \\
& Residual & 36 & 7.40 & 0.21 & & \\
\hline
\end{tabular}


Continuation Table 5.

\begin{tabular}{ccccccc}
\hline & \multicolumn{2}{c}{ Value } & & & & \\
\hline Horizon/Moisture & Source of variation & DF & SS & MS & F & p-value \\
\hline \multirow{2}{*}{ E / Moist } & Evaluation method & 3 & 47.28 & 15.76 & 103.15 & $9.75 \mathrm{E}-18$ \\
& Residual & 36 & 5.50 & 0.15 & & \\
\hline \multirow{2}{*}{ Bt / Dry } & Evaluation method & 3 & 1.00 & 0.33 & $1.62^{\text {ns }}$ & 0.20 \\
& Residual & 36 & 7.40 & 0.21 & & \\
Bt / Moist & Evaluation method & 3 & 9.90 & 3.30 & 16.50 & $6.55 \mathrm{E}-07$ \\
& Residual & 36 & 7.20 & 0.20 & & \\
\cline { 2 - 6 } Ap / Dry & Evaluation method & 3 & 0.28 & 0.09 & $0.73^{\text {ns }}$ & 0.54 \\
& Residual & 36 & 4.50 & 0.13 & & \\
Ap / Moist & Evaluation method & 3 & 1.40 & 0.47 & $2.40^{\text {ns }}$ & 0.08 \\
& Residual & 36 & 7.00 & 0.19 & & \\
\hline \multirow{2}{*}{ E / Dry } & Evaluation method & 3 & 5.10 & 1.70 & 4.78 & 0.01 \\
& Residual & 36 & 12.80 & 0.36 & & \\
\multirow{2}{*}{ E / Moist } & Evaluation method & 3 & 22.10 & 7.37 & 88.40 & $1.14 \mathrm{E}-16$ \\
& Residual & 36 & 3.00 & 0.08 & & \\
\hline \multirow{2}{*}{ Bt / Dry } & Evaluation method & 3 & 28.88 & 9.63 & 15.68 & $1.10 \mathrm{E}-06$ \\
& Residual & 36 & 22.10 & 0.61 & & \\
Bt / Moist & Evaluation method & 3 & 14.70 & 4.90 & 4.50 & 0.01 \\
& Residual & 36 & 39.20 & 1.09 & & \\
\hline
\end{tabular}

ns - not significant.

Figure 2 contains the means for value and chroma, with the respective standard deviations, compared by the Tukey test at a 5\% significance level. For value, it was possible to statistically prove the high variability among pedologists and their dissimilarity with the smartphone application, because in only two of the six situations analyzed there was an average of at least one pedologist statistically equal to that of the application. For chroma, however, the means obtained were in general statistically equal between the evaluation methods. 

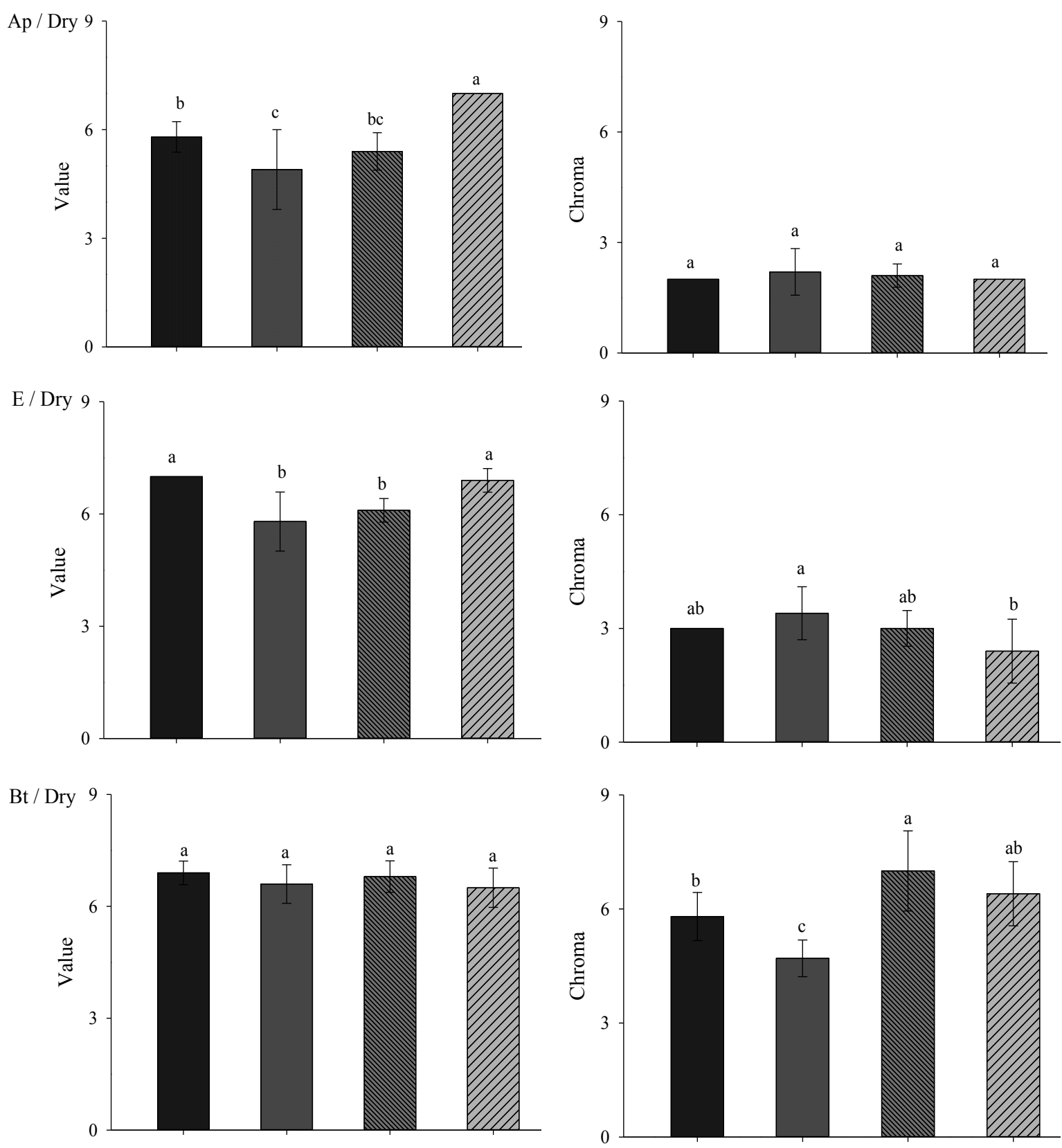

Figure 2. Means with standard deviations for value and chroma obtained by pedologists and smartphone application in the Ap, E, and Bt horizons of an Argissolo (Lixisol). Means followed by the same letter do not differ by Tukey test at 5\% significance level.

The contrasts of the means emphasize what was observed in the percentage of agreement (Figure 2 and Table 4), as the evaluation of the three-color components for all conditions (horizon and moisture) showed, on average, a lower agreement between pedologists and smartphone application for the perception of value. In general, with significant differences between pedologists, there is an indication of the variability due to different human perceptions in the assessment of the same phenomenon, in this case, the expression of color tone - and, of course, differences when compared to the smartphone. 
Thus, it is possible to indicate that the variation in intensity degree of spectral purity of the color represented by chroma was more easily identified, exhibiting more homogeneous behavior and, as a result, higher efficiency and repeatability among the values observed by the pedologists and the application. This indicates that, despite the limitations that the smartphone camera has to the human eye (especially in terms of visual field and spatial resolution), the application can be fully used in routine descriptions of soil color.

\section{CONCLUSIONS}

The agreement between pedologists and the smartphone application is medium for hue and chroma and low for value.

There is a high agreement between pedologists and the smartphone application in the perception of color in dry soil condition, especially in the perception of hue and chroma.

Although the smartphone camera has limitations of visual field and spatial resolution to the human eye, the application has the potential to be used in routine descriptions of soil color; reducing problems related to the subjectivity and variability of traditional soil color assessment by pedologists.

Conflict of interest: The authors declare that there is no conflict of interest.

\section{BIBLIOGRAPHIC REFERENCES}

Broken Oak studios. (2017). Soil Analysis Pro. Recovered from https://cutt.ly/xvV6eEt
FAO - Food and Agriculture Organization. (2014). World reference base for soil resources. Italy: Food and Agriculture Organization (FA0). 203 p.

Fan, Z.; Herrick, J.E.; Saltzman, R.; Matteis, C.; Yudina, A.; Nocella, N.; Crawford, E.; Parker, R.; Van Zee, J. (2017). Measurement of soil color: a comparison between smartphone camera and the Munsell color charts. Soil Science Society of America Journal, 81, 1139-1146. doi: 10.2136/ sssaj2017.01.0009

Han, P.; Dong, D.; Zhao, X.; Jiao, L.; Lang, Y. (2016). A smartphone-based soil color sensor: for soil type classification. Computers and Electronics in Agriculture, 123, 232-241. doi: https://doi. org/10.1016/j.compag.2016.02.024.

Jahn, R.; Blume, H. P.; Asio, V. B.; Spaargaren; O; Schad, P. (2006). Guidelines for soil description. $8^{\circ}$ ed. Rome: Food and Agriculture Organization (FAO). 97 p.

Kirillova, N.P.; Grauer-gray, J.; Harteminkb A.E.; Sileovaa, T.M.; Artemyevac, Z.S.; Burova, E. K. (2018). New perspectives to use Munsell color charts with electronic devices. Computers and Electronics in Agriculture, 155, 378-385. doi: https://doi.org/10.1016/j. compag.2018.10.028

Marqués-Mateu, Á.; Moreno-Ramón, H.; Balasch, S.; Ibáñez-Asensio, S. (2018). Quantifying the uncertainty of soil colour measurements with Munsell charts using a modified attribute agreement analysis. Catena, 171, 44-53. doi: https://doi.org/10.1016/j.catena.2018.06.027

Munsell Color Company. (2009). Munsell Soil Color Charts. United States: X-rite. 36 p.

Pegalajar, M. C.; Ruiz, L. G. B.; Sánchez-Marañón, M.; Mansilla, L. (2019). A Munsell colour-based approach for soil classification using Fuzzy Logic and Artificial Neural Networks. Fuzzy Sets and Systems. doi: https://doi.org/10.1016/j. fss.2019.11.002

Pongnumkul, S.; Chaovalit, P.; Surasvadi, N. (2015). Applications of Smartphone-Based Sensors in Agriculture: A Systematic Review of Research. Journal of Sensors. 18. doi: https:// doi.org/10.1155/2015/195308 
Santos, H. G.; Jacomine, P. K. T.; Anjos, L. H. C.; Oliveira, V. A.; Lumbreras, J. F.; Coelho, M. R., Almeida, J. A.; Araujo Filho, J. C.; Oliveira, J. B.; Cunha, T. J. F. (2018). Sistema brasileiro de classificação de solos. $5^{\circ}$ ed. Brasília: Embrapa. $590 \mathrm{p}$.

Skorka, O.; Dileepan, J. (2011). Toward a digital camera to rival the human eye. Journal of Electronic Imaging. 20(3). doi: https://doi. org/10.1117/1.3611015

Stiglitz, R.; Mikhailova, E.; Post, C.; Schlautman, M.; Sharp, J. (2016). Evaluation of an inexpensive sensor to measure soil color. Computers and Electronics in Agriculture. 121: 141-148. doi: https://doi.org/10.1016/j. compag.2015.11.014

Stiglitz, R.; Mikhailova, E.; Post, C.; Schlautman, M.; Sharp, J. (2020). Using an inexpensive color sensor for rapid assessment of organic carbon. Geoderma. 286: 98-103.doi: https://doi. org/10.1016/j.geoderma.2016.10.027

Stiglitz, R.; Mikhailova, E.; Post, C.; Schlautman, M.; Sharp, J.; Pargas, R.; Glover, B.; Mooney, J. (2017). Soil color sensor data collection using a GPSenabled smartphone application. Geoderma. 296: 108-114. doi: https://doi.org/10.1016/j. geoderma.2017.02.018

Simon, T.; Zhnag, Y.; Hartemink, A. E.; Huang, J.; Water, C.; Yost, J.L. (2020). Predicting the color of sandy soils from Wisconsin, USA. Geoderma. 361. doi: https://doi.org/10.1016/j.geoderma. 2019.114039

Vieira, J. M. (2013). Contribuição de compostos de baixa cristalinidade e ciclos de umedecimento e secagem na gênese do caráter coeso em solos do Ceará. Recovered from https://cutt.ly/8vV6dOB 